\title{
Organic Microbiological Studies: Effects of Organic Dyes(GentianViolet or Methylene Blue)On Laser Lethal photosensitization of Fungus Aspergillus flavus Treated with Boric Acid
}

\author{
Shakir M. Saied \\ Dept. of Pharmacy, Institute of Technical Mosul
}

Received"

Accepted

$15 / 6 / 2006$ 2006/8/17

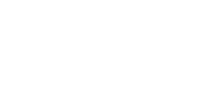

تزيد الصابغلت العضوية(الجتشن البفسجية او المثلين الزرقاء ) ت أثير القت لـ الفط ـر الإسبرجيلس فلافوس عند معلملة البيئت المحضرة بترلكيز مختلفة من حلمض البورية البوريك (1) و2\%) ثم تشعيعها ب بضوء ليزر الهليومانيون

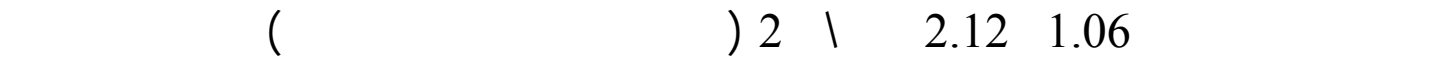
النتائج أن الزياة في تشبط نمو النطر عند تلوينه بصبغة الجنتشن البفنجية تصل إل مى 92.2 996.6\% من نمو الفطر (نسبة القل بالفرق عن القيلسي PDC ) في حين كان التبيط 84.4 و87.7\% عند تلوينه بصبغة الميثيلين الزرقاء .

\section{Abstract}

Organic Dyes (Gentian Violet or Methylene Blue) had increased the lethal photosensitization of Aspergillus flavus, when were treated with boric acid of different concentrations $(1 \%$ and $2 \%)$ and exposed to $\mathrm{He}-\mathrm{Ne}$ laser light with absorbed doses of 1.06 and 2.12 joules $/ \mathrm{cm}^{2}$ respectively and survivors enumerated.

The inhibition of fungus growth was 92.2 and $96.6 \%$ (Percentage differences from control PDC) for the coloring by Gentian Violet and 84.4and $87.7 \%$ for Methylene Blue.

\section{Introduction:}

Aspergillus species are saprophytic fungi found in soil, water and decaying organic matter ${ }^{[1]}$. Of the 200 species in the genus only a few can cause disease and Aspergillus flavus is one of them. In the normal host, Aspergillus species can cause a wide spectrum of diseases ranging from allergic manifestations, corrneal, otomycotic , nasoorbital infections and superficial infections to a life-threatening invasive disease known as invasive Aspergillosis ${ }^{[1-2]}$.Initiation of infection begins with the inhalation of conidia, the infectious particles, which adhere to and germinate in the lung tissue ${ }^{[3]}$. Hyphal invasion of the lung epithelium is followed by 
dissemination to other organs risk factors for invasive Aspergillosis is prolonged neutropenia and/or long-term administration of high dose corticosteroids $^{[3]}$.

Although Aspergillus fumigatus is the most common cause of Aspergillosis, but A. flavus, and several other species can also cause diseases. Aspergillus is a mold with septate hyphae about $2-4$ um in diameter. The fungus can be identified by its gross and microscopic appearance in culture ${ }^{[4]}$.

The extremely effective of boric acid on the growth of some fungi or their aflatoxin

, and the lethal photosensitization of these fungi at exposure to $\mathrm{He} / \mathrm{Ne}$ laser light or Gallium Aluminium Arsenide laser irradiations with different dyes( toluidine blue or methylene blue) was studied by many investigators ${ }^{[5-9]}$.

As part of continuous program directed toward the studying of the biological effects of some organic and inorganic compounds ${ }^{[6]}$, it was become of interest to investigate a comparative study between the effects of this acid in different concentrations ( $1 \%$ and $2 \%$ ), and the lethal photosensitization toward $\mathrm{He}-\mathrm{Ne}$ laser light after colored with gentian violet or methylene blue.

\section{Materials and methods test organism}

Aspergillus flavus, a fungus previously isolated from corns was used in this work.

\section{Inoculums preparation ${ }^{[9]}$}

Sabaurauds Agar medium (SAM) was used, with the following composition (g/l): Glucose, 10; Agar, 10, Pepton10 and distilled water, $1000 \mathrm{ml}$. The $\mathrm{pH}$ value of the medium was adjusted at 5.6 then autoclaving at $1.5 \mathrm{~atm}$. for 15 minutes. (SAM) medium was also used for subculturing of the test organism as well as for preparation of fungal inoculum. This was prepared in the form of fungal culture discs each of $7 \mathrm{~mm}$ diameter using 8 days old culture. (SAM) medium was also used as control medium for measuring the toxicity of boric acid on fungal growth.

\section{Experimental media}

This was prepared using (SAM) medium.It was supplied singly by different concentrations of boric acid of $1 \%$ and $2 \%$. The days(gentian violet and methylene blue) was supplied as $0.0001 \%$.

\section{Expressions of results}

Fungal growth was determined by measuring the diameter of colony radial growth in $\mathrm{mm}$. Data were recorded in triplicates after 8days of incubation at $28^{\circ} \mathrm{C}$, and $5-10$ mins laser irradiations of the coloring samples. Results were expressed as percentage difference from control (\% PDC). 


\section{Laser used}

Laser $\mathrm{He}-\mathrm{Ne}$ of wave length $632.8 \mathrm{~nm}$ and power output of 0.001 watt, irradiations techniques was provided in Laser Laboratory, Department of Physics, College of Education ,Mosul University. 

Table (1)

Colony Diameter \& \%Inhibition of Aspergillus flavus on (SAM) medium Colored with gentian violet and supplied with different conditions of (Boric acid concentrations and irradiation absorbed dose).

\begin{tabular}{|c|c|c|c|c|c|c|c|c|}
\hline \multirow{3}{*}{$\begin{array}{c}\text { Boric } \\
\text { acid } \\
\text { Conc. } \\
(\%)\end{array}$} & \multicolumn{4}{|c|}{8 Days without radiation } & \multicolumn{4}{|c|}{8 Days ( colored with gentian violet)and irradiation with absorbed dose $\left(\text { in joules } / \mathrm{cm}^{2}\right)^{*}$} \\
\hline & \multicolumn{2}{|c|}{ uncolored } & \multicolumn{2}{|c|}{$\begin{array}{c}\text { colored with gentian } \\
\text { violet }\end{array}$} & \multicolumn{2}{|c|}{1.06} & \multicolumn{2}{|c|}{2.12} \\
\hline & $\begin{array}{c}\text { Colony } \\
\text { Diameter } \\
(\mathrm{mm})\end{array}$ & $\begin{array}{c}\% \\
\text { Inhibition }\end{array}$ & $\begin{array}{c}\text { Colony } \\
\text { Diameter } \\
(\mathrm{mm})\end{array}$ & $\begin{array}{c}\% \\
\text { Inhibition }\end{array}$ & $\begin{array}{c}\text { Colony } \\
\text { Diameter } \\
(\mathrm{mm})\end{array}$ & $\begin{array}{c}\% \\
\text { Inhibition }\end{array}$ & $\begin{array}{c}\text { Colony } \\
\text { Diameter } \\
(\mathrm{mm}) \\
\end{array}$ & $\begin{array}{c}\% \\
\text { Inhibition }\end{array}$ \\
\hline 0.0 & 90 & 0 & 71 & 78.8 & 77 & 85.5 & 80 & 88.8 \\
\hline $1 \%$ & 30 & 33.1 & 72 & 80 & 81 & 90 & 83 & 92.2 \\
\hline $2 \%$ & 40 & 44.6 & 74 & 82.2 & 85 & 94.4 & 87 & 96.6 \\
\hline
\end{tabular}

Table (2)

Colony Diameter \& \% Inhibition of Aspergillus flavus on (SAM) medium Colored with Methylene Blue and supplied with different conditions

\begin{tabular}{|c|c|c|c|c|c|c|c|c|}
\hline \multirow{3}{*}{$\begin{array}{l}\text { Boric } \\
\text { acid } \\
\text { Conc. } \\
(\%)\end{array}$} & \multicolumn{4}{|c|}{8 Days without radiation } & \multicolumn{4}{|c|}{8 Days(colored with methylene blue)and irradiation with absorbed dose (in joules $/ \mathrm{cm}^{2}$ ) } \\
\hline & \multicolumn{2}{|c|}{ uncolored } & \multicolumn{2}{|c|}{$\begin{array}{c}\text { colored with } \\
\text { Methylene Blue }\end{array}$} & \multicolumn{2}{|c|}{106.16} & \multicolumn{2}{|c|}{212.32} \\
\hline & $\begin{array}{c}\text { Colony } \\
\text { Diameter } \\
(\mathrm{mm})\end{array}$ & $\begin{array}{c}\% \\
\text { Inhibition }\end{array}$ & $\begin{array}{l}\text { Colony } \\
\text { Diameter } \\
(\mathrm{mm})\end{array}$ & $\begin{array}{c}\% \\
\text { Inhibition }\end{array}$ & $\begin{array}{c}\text { Colony } \\
\text { Diameter } \\
(\mathrm{mm})\end{array}$ & $\begin{array}{c}\% \\
\text { Inhibition }\end{array}$ & $\begin{array}{c}\text { Colony } \\
\text { Diameter } \\
(\mathrm{mm}) \\
\end{array}$ & $\begin{array}{c}\% \\
\text { Inhibition }\end{array}$ \\
\hline 0.0 & 90 & 0 & 62 & 68.8 & 72 & 80 & 74 & 82.2 \\
\hline
\end{tabular}





\section{Results and discussions}

Organic dyes were used very extensively as anti-infective agents before the discovery of the sulfonamides and the antibiotics, and few cationic dyes still find limited use as anti-infective ${ }^{[10]}$. These include the triphenyl methane dyes gentian violet and the thiazine dye methylane blue.Cationic dyes were active against Gram-positive bacteria and generally resistant .The difference in susceptibility was probably related to the cellular characteristics that underlined the Gram stain ${ }^{[10]}$

The dehydration power effects of boric acid on the fungal biochemistry was clearly associated with damage of the cell membrane with the loss of essential cellular components such as potassium ions and amino acids, and these effects are increased by the laser light irradiation ${ }^{[11-12]}$.

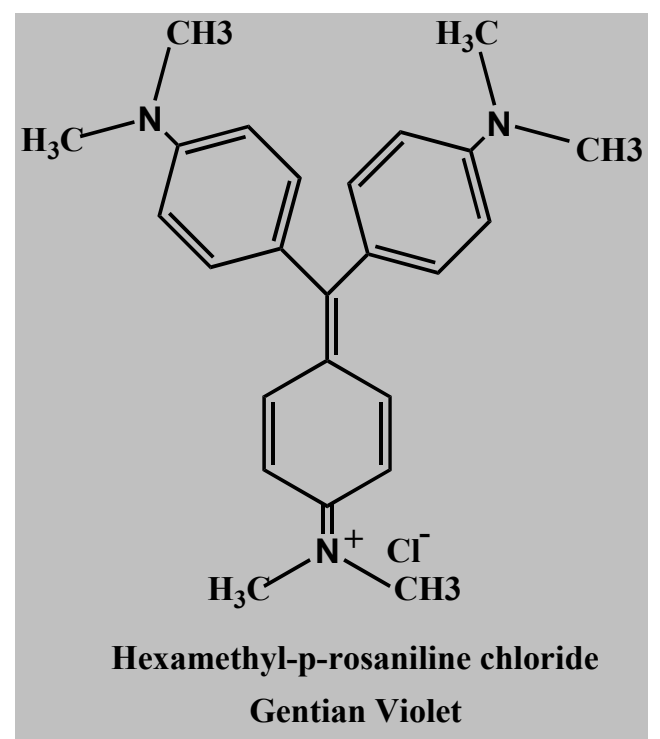

Stean and Stearn indicated that the behavior of bacteria toward dyes could be explained and largely determined by its $\operatorname{protein}^{[13]}$. This behavior is increased when these dyes irradiated by laser. The use of gentian violet or methylene blue was based on the ability of these organic dyes to absorb the energy of a source and then irradiates the energy as laser irradiation. ${ }^{[8]}$

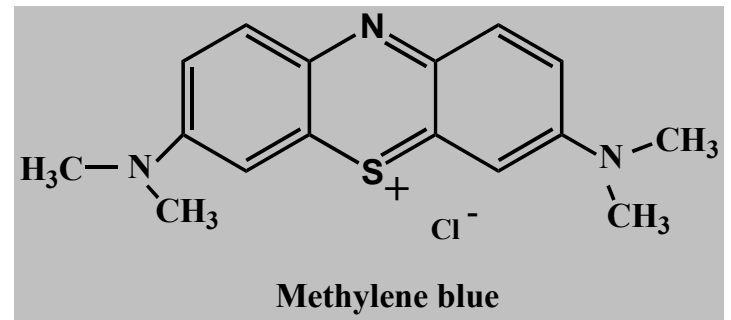

Results presented in Tables (1) show that the coloring by organic dye Gentian Violet increases the lethal photosensitization of Aspergillus 
flavus, i.e. increases the \% inhibition of fungus growth (Percentage differences from control) from 33.1and 44.6 (of the two concentrations of boric acid) to 92.2 and 96.6 when irradiation with absorbed dose 1.06 joules $/ \mathrm{cm}^{2}$, and from 33.1 and 44.6 to 92.2 and 96.6 when irradiation with absorbed dose 2.12 joules $/ \mathrm{cm}^{2}$. While results presented in Tables (2) show that the coloring by organic dye Methylene Blue increases this \% inhibition from 33.1 and 44.6 to 92.2 and 96.6 when irradiation with absorbed dose 1.06 joules/ $/ \mathrm{cm}^{2}$, and from 33.1 and 44.6 to 92.2 and 96.6 when irradiation with absorbed dose 2.12 joules $/ \mathrm{cm}^{2}$. The inhibition by boric acid without irradiation of growth in our early work was from 33.1 and $44.6 \%{ }^{[6]}$

What was made these two dyes to be so suitable as laser absorbance? In the first place the $\mathrm{C}=\mathrm{N}$ and the $(\mathrm{CH} 3)_{2} \mathrm{~N}$ - moieties were produced extensive conjugated system. The more extensive the molecular conjugation, the smaller the energy gap between the highest filled $\pi$ orbital and the lowest empty $\pi^{*}$ orbital, then even range may be sufficient to excite the molecule. This was increased the lethal photosensitization of the culture of Aspergillus flavus. ${ }^{[14]}$

\section{Conclusion}

Using organic dyes (Gentian Violet or Methylene Blue) of violet pigment enables a large amount of He-Ne laser light energy to focus into a small area, thereby creating a much greater photochemical UV cataract reaction than ordinary light, producing irradiation absorbed dose of about 1.06 and 2.12 joules $/ \mathrm{cm}^{2}$ for 5 and 10 minutes respectively, and this doses increase the thermal damage accompanied with the killing effects of inorganic molecules (boric acid), this incubation of the photosensitizes with the yeast was necessary to render it susceptible to killing by laser light.

\section{Acknowledgment}

I thank Dr. Abdulla, A.I.; Asst. professor of Laser Physics, department of physics, College of Education , Mosul University, for providing the laser irradiations techniques .

\section{References}

[1]Broderick, L. S., Conces, D. J.Jr, Tarver, R. D., Bergmann, C. A. and Bisesi, M. A.;( Pulmonary Aspergillosis: A Spectrum of Disease); Crit Rev Diagn Imaging 37, 491-531 (2006).

[2] (Aspergillus flavus), Wikipedia, the free encyclopedia; http://en.wikipedia.org/wiki/Aspergillus_flavus; 23-33(2006) 
[3] Latge, J. P; (Aspergillus fumigatus and Aspergillosis) ; Clin Microbiol Rev 12, 310-350 (1999).

[4] John E. Bennett; (Aspergillosis) ;Teton Data System, Search Engine, V 4.4.9, McGraw-Hill; 206( 2001)

[5] Raisuddin,S and Misra,JK.; (Aflatoxin in Betel Nut and Its Control By Use of Food Preservatives); Preventive Toxicology Div., Industrial Toxicology Res. Ctr., Post Box No. 80, M. Ghandi Marg, Lucknow 226 001, India(1991)

[6] Saied,S.M.,Basheer,A.A.and Al-Obaydi,Gh.F.;Organic Microbiological Studies (The Effects of Gentian Violet and Boric Acid on Growth of the Fungi Aspergillus flavus, Penicillium chrysogenum and Penicillium expansum);Dept. Of Pharmacy Institute of Technical/Mosul;(under publication)

[7] Hashem,A.R.andAl-Obaid,A.M.;(Effect of Cadmium on The Growth of Aspergillus flavus and Ulocldium chlamydosporium); International Journal of Experimental Botany 59 (1/2): 171-175. (1996)

[8] Wilson,M. and Mia,N.;( Effect of Environmental Factors on The Lethal Photosensitization of Candida albicans in Vitro); Department of Microbiology, Eastman Dental Institute, University of London, 256 Grays Inn Road, London WC1X 8LD, United Kingdom(1994)

[9]Pitt,J.I. and Hocking A.D.(Fungi and Food Spoilage) $2^{\text {nd }}$ aithersburg,Maryland:Chapman and Hall.593(1997)

[10]Block,J.H. and Beale,J.M. "Wilson and Gisvold,s Text Book of Organic Medicinal and Pharmaceutical Chemistry" $11^{\text {th }}$ Edd.,Lippincott Williams \&Wilkins,Philadelphia,USA(2004) .

[11] Hitchcock,C.A.;(Boric Acid/ Borates/ Borax ,Beyond Pesticides Rating: Least Toxic, Use and Mode of Action), Biochem.Soc.Trans;email info@,beyondpesticides.org;199:782 (1991)

[12] Frank J. Duarte;(Duarte Dye Laser Principles with Applications); Academic Press; 10-20(1990).

[13] Stearn E.W.and Stearn,;A.E.;(The Chemical Mechanism of Bacterial Behavior) .J.of Bact.,v.9(5),(1925)

[14] Alexander,R.; (The Dye Laser), the Laser Electro-Optic Program at Albuquerque Technical-Vocational Institute; Dye_Laser.htm; (1992) 